\section{DISTRIBUTION AND HABITAT PREFERENCES OF TIGER BEETLES (COlEOPTERA: CicindelidAe) OF THE RIVERINE ECOSYSTEMS OF SRI LANKA}

\section{Chandima D. Dangalle ${ }^{1}$, Nirmalie Pallewatta ${ }^{2}$ \& Alfried P. Vogler ${ }^{3}$}

1,2 Department of Zoology, Faculty of Science, University of Colombo, Cumaratunga Munidasa Mawatha, Colombo 03, P.O. Box 00300, Sri Lanka

${ }^{3}$ Department of Entomology, The Natural History Museum, Cromwell Road, London, SW7 5BD, United Kingdom

${ }^{1}$ cddangalle@gmail.com (corresponding author), ${ }^{2}$ nirmalip@yahoo.com, ${ }^{3}$ a.vogler@nhm.ac.uk

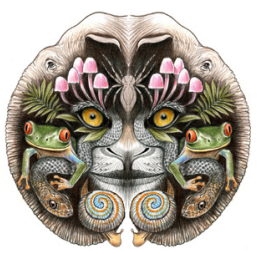

ISSN

Online 0974-7907

Print 0974-7893

Abstract: Tiger beetles have been observed in many riverine ecosystems of Sri Lanka. However, current locations, species, distribution of species, habitat preferences and possible interactions between species are unknown. The present study intends to investigate these details and provide information that can be used in further studies. Tiger beetles are sampled from 15 riverine locations and examined for identification, body weight and body length. The riverine locations are analysed for locational, climatic and soil parameters and microhabitat details are recorded. Statistical analysis using One-Way Analysis of Variance and Tukey's pair comparison method of Minitab 16.0 statistical software package is conducted to compare the body sizes of species. Further, a statistical comparison between the climatic and soil parameters of the locations of Cylindera (Ifasina) labioaenea and that of other species are carried out. The study reveals five tiger beetle species Cylindera (Ifasina) labioaenea Horn, Cylindera (Ifasina) willeyi Horn, Cylindera (Ifasina) waterhousei Horn, Calomera cardoni Fleutiaux, Calomera angulata Fabricius, from the riverine ecosystems of Sri Lanka. Cylindera labioaenea is the most common species; $C$. willeyi and C. waterhousei are endemic to Sri Lanka. Cylindera labioaenea, C. willeyi and C. waterhousei are small, while Calomera cardoni and Calomera angulata are medium in size. Cylindera labioaenea is significantly smaller than $C$. willeyi and $C$. waterhousei, and resides in locations with significantly higher air temperatures, solar radiations and significantly lower relative humidity than the other two species. An optimal temperature range for the riverine tiger beetles is suggested and their preferences to soil moisture, soil temperature, soil colour and soil salinity are discussed. The occurrence of $C$. labioaenea as a single species population while the fact that other species co-exist may be due to a defensive strategy.

Keywords: Body size, Cicindelidae, climatic and soil preferences, riverine ecosystems, tiger beetles.

DOI: http://dx.doi.org/10.11609/JoTT.03674.6195-203 | ZooBank: urn:Isid:zoobank.org:pub:2AFE4FBF-85CB-4804-A120-C17F3F9550F7

Editor: Anonymity requested.

Date of publication: 26 August 2014 (online \& print)

Manuscript details: Ms \# 03674 | Received 22 June 2013 | Final received 12 July 2014 | Finally accepted 28 July 2014

Citation: Dangalle, C.D., N. Pallewatta \& A.P. Vogler (2014). Distribution and habitat preferences of tiger beetles (Coleoptera: Cicindelidae) of the riverine ecosystems of Sri Lanka. Journal of Threatened Taxa 6(9): 6195-6203; http://dx.doi.org/10.11609/JoTT.03674.6195-203

Copyright: @ Dangalle et al. 2014. Creative Commons Attribution 4.0 International License. JoTT allows unrestricted use of this article in any medium, reproduction and distribution by providing adequate credit to the authors and the source of publication.

Funding: The study has been supported by grant number RG/2003/ZOO/01 and RG/2012/NRB/02 from the National Science Foundation of Sri Lanka.

Competing Interest: The authors declare no competing interests.

Author Contribution: CDD conducted the literature survey on distribution and habitat preferences of tiger beetles of Sri Lanka and conducted field studies and sampling. She contributed towards research design and methodology and writing of the paper. NP contributed towards formulating the initial concept, research design and methodology. APV contributed by formulating the initial concept.

Author Details: DR. CHANDIMA DANGalle is a senior lecturer in Zoology. Her expertise lies in the fields of entomology and molecular biology. Her research focuses on collecting baseline data on the distribution and habitat preferences of tiger beetles in Sri Lanka and in evolution and phylogeny of the species. Dr. Dangalle conducted her PhD in the Department of Zoology, University of Colombo, Sri Lanka and Department of Entomology, Natural History Museum, London, United Kingdom. DR. NIRMALIE PALLEWATTA is a senior lecturer and the current head of the Department of Zoology, University of Colombo, Sri Lanka. A zoologist by training, Pallewatta received her PhD in 1986 from the Imperial College of Science, Technology and Medicine at the University of London, United Kingdom. Prof. ALFRIED VOGLER works on the molecular systematics of Coleoptera. He has a joint position at the Natural History Museum and at Imperial College, London, United Kingdom. Together with PhD students and postdocs, he is currently working on the insect fauna of Madagascar, to establish the causes of endemicity and diversity, based on large-scale DNA sequencing of entire communities.

Acknowledgements: We wish to thank the Department of Wildlife Conservation, Ministry of Environment, Sri Lanka for providing permits necessary for field work and sample collection. We are grateful to Prof. Nimal Dangalle, Department of Geography, University of Kelaniya, Sri Lanka for his assistance in the preparation of maps and list of locations. 


\section{INTRODUCTION}

Tiger beetles (Coleoptera: Cicindelidae) are colourful insects that are distributed worldwide. They have been studied intensively in many countries and are among the few insect groups for which endangered species are declared and placed on national Red Lists (Pearson 2011).

Fifty-nine species of tiger beetles have been recorded from Sri Lanka, of which 39 are endemic (Dangalle et al. 2012a). The genera Collyris, Neocollyris, Tricondyla and Derocrania consists of arboreal species, while the majority of species are included in the genus Cicindela (currently split into a large number of genera, according to Pearson et al. 2006) which is terrestrial (Dangalle et al. 2011a). The terrestrial species are found in a variety of sandy, open environments of which most tend to prefer the riverine habitat because of close proximity to water and food resources and safety from predators (Bhargav \& Uniyal 2008; Dangalle et al. 2012a). Only nine species of tiger beetles are so far known from the riverine ecosystems of the island amongst vegetation and on sandy banks along small to large rivers (Table 1).

Currently, riverine ecosystems of many countries are facing threats from land development and agricultural practices that lead to loss of riverine invertebrates (Hudgins et al. 2011). Off-road vehicles and human traffic along Genesee River, New York has caused local extinctions of Cobblestone tiger beetles (Cicindela marginipennis) (Hudgins et al. 2011), while toxic chemicals and other water-borne pollutants in the Red River, China has threatened the survival of several tiger beetles (Shook \& Xiao-Qiang 2006). In Sri Lanka, the endemic species Cylindera (Ifasina) willeyi has become locally extinct from its historical riverine locations in the Central Province and Labugama, Western Province due to unsuitability and loss of these former habitats (Dangalle et al. 2011). However, records on tiger beetles of the riverine ecosystems of Sri Lanka are few, and specific habitat requirements and distribution of species are poorly understood. The increase in the island's population, accompanied by expansion of the land area under urban, agricultural and industrial development have contributed to the loss and reduction of extents of natural ecosystems their inherent species as well as genetic diversity. Therefore, it is imperative that the tiger beetles inhabiting the riverine ecosystems of Sri Lanka be recorded and investigated. The present study intends to record the tiger beetles of riverine ecosystems of Sri Lanka, investigate their current locations and distribution and record habitat preferences. The study will provide preliminary information that can be used in future studies for assessing their conservation status.

\section{MATERIALS AND METHODS}

\section{Study Area}

Forty-two riverine locations of Sri Lanka were investigated for the occurrence of tiger beetles from June 2003 to October 2006 and May 2013 to May 2014. These locations were situated in Colombo, Gampaha and Kalutara districts of the Western Province; Ratnapura and Kegalle districts of the Sabaragamuwa Province; Puttalam and Kurunegala districts of the North-Western Province; Anuradhapura District of the North-Central Province; Nuwara, Nuwara Eliya and Matale districts of the Central Province, and Hambantota District of the

Table 1. Tiger beetle species known from the riverine ecosystems of Sri Lanka (* denotes endemic species)

\begin{tabular}{|c|l|l|l|}
\hline & \multicolumn{1}{|c|}{ Species } & \multicolumn{1}{c|}{ Habitat } & \multicolumn{1}{|c|}{ Location } \\
\hline 1 & Lophyra (Lophyra) cancellata Dejean, 1825 & $\begin{array}{l}\text { Dry upper sandy banks along medium to } \\
\text { large rivers. }\end{array}$ & $\begin{array}{l}\text { Kurunegala (1979, 1981, 1983), Mahaweli Ganga } \\
(1981), \text { Kala Oya (1981, 1983) }\end{array}$ \\
\hline 2 & Calomera cardoni Fleutiaux, 1890 & Wet sandy banks of small to large rivers. & Kurunegala (1983), Mahaweli Ganga (1981) \\
\hline 3 & Calomera angulata Fabricius, 1798 & Moist, sandy river banks. & Locations unknown. \\
\hline 4 & Cylindera (Ifasina) waterhousei Horn, 1900* & $\begin{array}{l}\text { Vegetation and wet rocks along water } \\
\text { courses within dark, moist forests. }\end{array}$ & Labugama (1979), Karawanella (1979) \\
\hline 5 & Cylindera (Eugrapha) singalensis (Horn, 1911) & Along major rivers. & Hambantota (1921) \\
\hline 6 & Myriochila (Myriochila) undulata (Dejean, 1825) & Edges of small rivers. & Tissamaharama (1983) \\
\hline 7 & Myriochila (Myriochila) distinguenda (Dejean, 1825) & Along river edges. & $\begin{array}{l}\text { Puttalam (1981), Padaviya (1970), Kilinochchi } \\
\text { (1970), Mannar (1976) }\end{array}$ \\
\hline 8 & Hypaetha quadrilineata (Fabricius, 1781) & Along rivers. & Locations unknown. \\
\hline 9 & Callytron limosum (Saunders, 1834) & Along major rivers. & Chilaw (1979) \\
\hline
\end{tabular}

Source: Acciavatti \& Pearson 1989 
Southern Province. The locations consisted of major rivers, streams, water canals, ferrys and waterfalls. Each location was visited twice during the study period and river banks, sand bars, moist rocks and shrub areas were searched for beetles between 9.00 and $17.00 \mathrm{hr}$.

\section{Collection and Identification}

Tiger beetles were collected using a standard insect net and preserved in $70 \%$ alcohol. Permission to make collections was obtained through a permit issued by the Department of Wildlife Conservation, Ministry of Environment and Natural Resources of Sri Lanka.

Species identification was carried out according to the taxonomic keys of the Cicindela of the Indian Subcontinent by Acciavatti \& Pearson (1989), and descriptions of Horn (1904) and Fowler (1912). Nomenclature is based upon Wiesner (1992) except for the use of Calomera instead of Lophyridia, based upon Lorenz (1998).

\section{Measurement of body weight and body length}

Body weight and body length were estimated for 42 tiger beetles, viz: 21 specimens of Cylindera (Ifasina) labioaenea, eight specimens of Cylindera (Ifasina) willeyi, seven specimens of Cylindera (Ifasina) waterhousei, three specimens of Calomera cardoni and three specimens of Calomera angulata.

Body weight of the alcohol fixed beetles was determined to the nearest $\mathrm{mg}$ using an analytical balance (Chyo JL180, Chyo Balance Corp., Japan).

Body length was estimated by measuring the distance from the frons of the head to the elytral apex when the head was in the normal feeding position. Caudal spines on the elytral apex were disregarded. Based on the references of Acciavatti \& Pearson (1989), McCairns et al. (1997) and Zerm \& Adis (2001), body length of beetles were categorized as follows: less than $8 \mathrm{~mm}$ - very small, 8-10 mm - small, 10-15 mm - medium, 15-20 mm large, more than $20 \mathrm{~mm}$ - very large.

Measurements of body length were taken using a dissecting microscope (Nikon Corporation SE, Japan) with an ocular micrometer (Nikon, Tokyo, Japan) that was calibrated by a stage micrometer (Olympus, Japan).

\section{Measurement of Habitat Parameters}

Climatic and soil parameters of the riverine locations of tiger beetles were recorded in each visit using standard methods. The air temperature, solar radiation, relative humidity and wind speed were measured using a portable integrated weather station (Health EnviroMonitor, Davis Instrument Corp., Hayward, USA). The soil temperature (using Insert soil thermometer SG 68010 ), soil $\mathrm{pH}$ (using portable soil $\mathrm{pH}$ meter Westminister No.259), soil salinity (using an YSI model 30 hand-held salinity meter) and soil colour (measured by comparison with a Munsell soil colour chart (Year 2000 revised washable edition) were estimated in each selected habitat. Soil moisture was detected using a gravimetric method (determined by selecting five random spots of a given site, collecting samples to a depth of $10 \mathrm{~cm}$ and estimating the difference in weight before and after oven drying to $107-120^{\circ} \mathrm{C}$ in the laboratory).

\section{Statistical Analysis}

The body weights and body lengths of the five species were statistically compared. The climatic and soil parameters of the 10 locations of Cylindera (Ifasina) labioaenea were compared with the five locations of other species willeyi, waterhousei, cardoni, and angulata). Statistical comparisons were done using OneWay Analysis of Variance and Tukey's pair comparison method of the Minitab 16.0 statistical software package.

\section{RESULTS}

\section{Locations of tiger beetles}

Tiger beetles were encountered in 15 riverine locations of 42 locations investigated. They were recorded in the districts of Colombo, Gampaha, Kalutara of the Western Province; Ratnapura and Kegalle districts of the Sabaragamuwa Province and Puttalam, Kurunegala of the North-Western Province of Sri Lanka (Fig. 1 and Table 2). Beetles were found inhabiting river banks, amongst shrubs and grasses near the river and on moist rocks (Table 2 ).

\section{Recorded Species}

Five species Cylindera (Ifasina) labioaenea, Cylindera (Ifasina) willeyi, Cylindera (Ifasina) waterhousei, Calomera cardoni, Calomera angulata, were recorded from riverine locations of Sri Lanka (Image 1). C. labioaenea was the most common species and dominated the other species in terms of occurrence (Fig. 2). C. willeyi and C. waterhousei are endemic to Sri Lanka.

\section{Body Size}

Small and medium sized tiger beetles were recorded from riverine locations. Cylindera labioaenea, $C$. willeyi and $C$. waterhousei were categorized as small tiger beetles and Calomera angulata and C. cardoni were categorized 


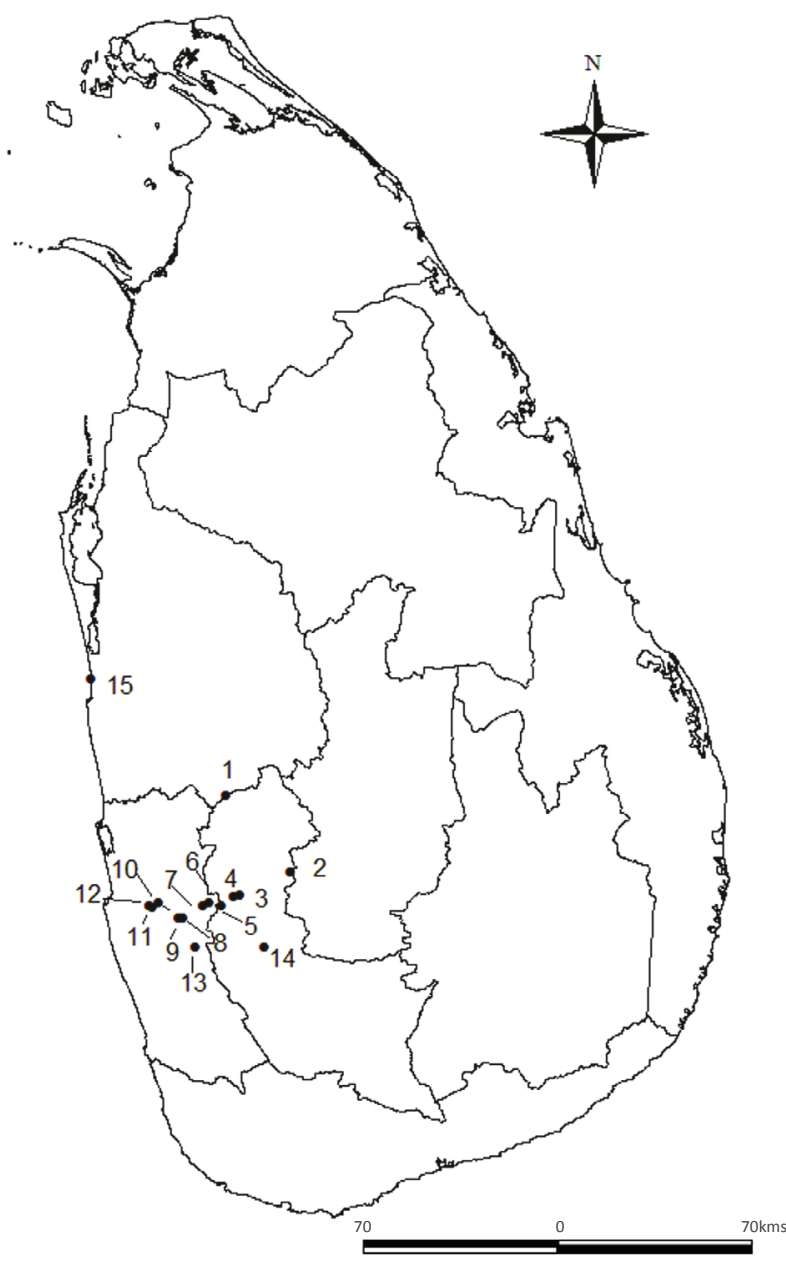

Figure 1. Sampling locations of tiger beetles

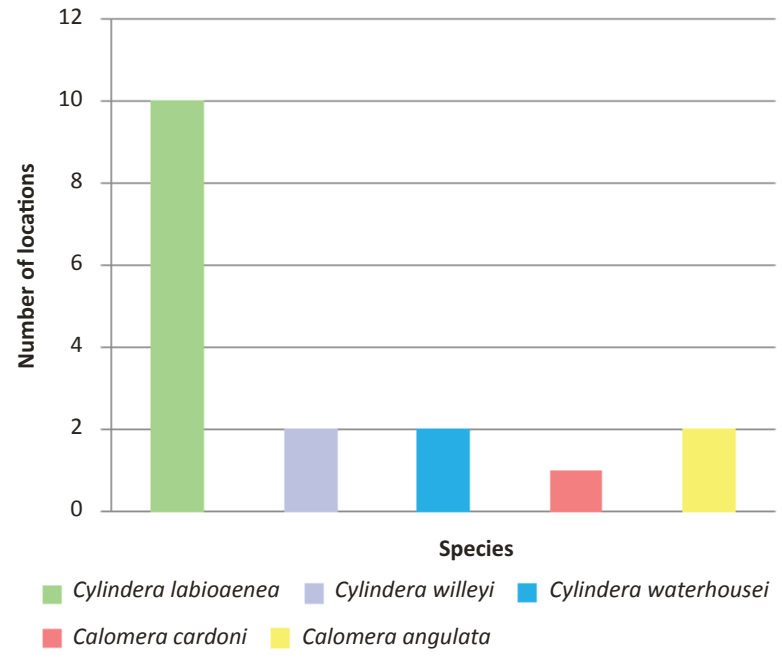

Figure 2. Occurrence of Tiger Beetle species in riverine locations of Sri Lanka
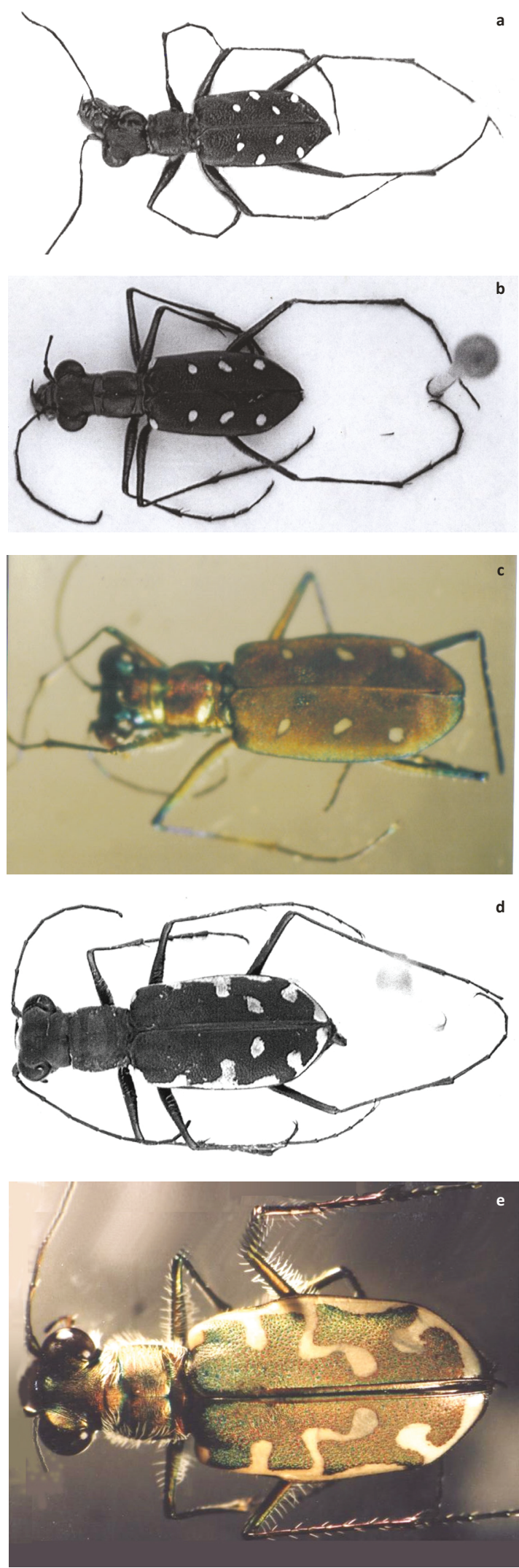

Image 1. Tiger beetle species of the riverine ecosystems of Sri Lanka. a - Cylindera (Ifasina) Iabioaenea; b - Cylindera (Ifasina) willeyi;

c - Cylindera (Ifasina) waterhousei; d - Calomera cardoni;

e - Calomera angulata. (c) Chandima Dangalle 
Table 2. Riverine locations of tiger beetles recorded during the study (Location number coincides with the numbers given in Figure 1. Each location was surveyed twice during the month denoted in the Survey Date).

\begin{tabular}{|c|c|c|c|c|c|c|}
\hline & Location & $\begin{array}{l}\text { Spatial coordinates } \\
\text { and elevation }\end{array}$ & $\begin{array}{l}\text { Habitat and } \\
\text { microhabitat }\end{array}$ & Survey date & Recorded species & $\begin{array}{l}\text { No. of } \\
\text { specimens } \\
\text { collected }\end{array}$ \\
\hline 1 & $\begin{array}{l}\text { Ma Oya, Alawwa, Kurunegala District, } \\
\text { North-Western Province }\end{array}$ & $\begin{array}{l}7^{\circ} 17^{\prime} 40 \mathrm{~N} \& 80^{\circ} 14^{\prime} 20 \mathrm{E} ; \\
45.1 \mathrm{~m}\end{array}$ & $\begin{array}{l}\text { Stream } \\
\text { Stream bank }\end{array}$ & July 2004 & $\begin{array}{l}\text { Calomera cardoni } \\
\text { Calomera angulata }\end{array}$ & $\begin{array}{l}03 \\
01\end{array}$ \\
\hline 2 & $\begin{array}{l}\text { We Oya, Yatiyantota, Kegalle District, } \\
\text { Sabaragamuwa Province }\end{array}$ & $\begin{array}{l}7^{\circ} 01^{\prime} 27 \mathrm{~N} \& 80^{\circ} 18^{\prime} 02 \mathrm{E} \\
31.0 \mathrm{~m}\end{array}$ & $\begin{array}{l}\text { Stream } \\
\text { Amongst shrubs of } \\
\text { river bank. }\end{array}$ & March 2005 & $\begin{array}{l}\text { Cylindera (Ifasina) } \\
\text { labioaenea }\end{array}$ & 03 \\
\hline 3 & $\begin{array}{l}\text { Maha Oya Falls, Dehi Owita, } \\
\text { Colombo Distict, Kegalle District, } \\
\text { Sabaragamuwa Province }\end{array}$ & $\begin{array}{l}6^{0} 58^{\prime} 03 \mathrm{~N} \& 80^{\circ} 16^{\prime} 56 \mathrm{E} ; \\
39.3 \mathrm{~m}\end{array}$ & $\begin{array}{l}\text { Waterfall } \\
\text { Moist rocks }\end{array}$ & August 2003 & $\begin{array}{l}\text { Cylindera (Ifasina) } \\
\text { labioaenea }\end{array}$ & 03 \\
\hline 4 & $\begin{array}{l}\text { Maha Oya, Dehi Owita, Kegalle } \\
\text { District, Sabaragamuwa Province }\end{array}$ & $\begin{array}{l}6^{0} 57^{\prime} 91 \mathrm{~N} \& 80^{\circ} 16^{\prime} 44 \mathrm{E} \\
6.7 \mathrm{~m}\end{array}$ & $\begin{array}{l}\text { Stream } \\
\text { Among shrubs of } \\
\text { river bank. }\end{array}$ & August 2003 & Cylindera (Ifasina) willeyi & 07 \\
\hline 5 & $\begin{array}{l}\text { Seethavaka River, Thalduwa, } \\
\text { Colombo District, Western Province }\end{array}$ & $\begin{array}{l}6^{\circ} 54^{\prime} 21 \mathrm{~N} \& 80^{\circ} 07^{\prime} 40 \mathrm{E} ; \\
18.3 \mathrm{~m}\end{array}$ & $\begin{array}{l}\text { Major river } \\
\text { River bank }\end{array}$ & August 2003 & $\begin{array}{l}\text { Cylindera (Ifasina) } \\
\text { labioaenea }\end{array}$ & 01 \\
\hline 6 & $\begin{array}{l}\text { Asvathu Oya, Awissawella, Colombo } \\
\text { District, Western Province }\end{array}$ & $\begin{array}{l}6^{0} 56^{\prime} 66 \mathrm{~N} \& 80^{\circ} 10^{\prime} 66 \mathrm{E} \\
16.5 \mathrm{~m}\end{array}$ & $\begin{array}{l}\text { Stream } \\
\text { River bank }\end{array}$ & July 2003 & $\begin{array}{l}\text { Cylindera (Ifasina) } \\
\text { labioaenea }\end{array}$ & 04 \\
\hline 7 & $\begin{array}{l}\text { Water canal, Puvakpitiya, Colombo } \\
\text { District, Western Province }\end{array}$ & $\begin{array}{l}6^{0} 15^{\prime} 58 \mathrm{~N} \& 80^{\circ} 11^{\prime} 14 \mathrm{E} ; \\
16.0 \mathrm{~m}\end{array}$ & $\begin{array}{l}\text { Water canal } \\
\text { Amongst shrubs of } \\
\text { river bank. }\end{array}$ & June 2003 & $\begin{array}{l}\text { Cylindera (Ifasina) } \\
\text { labioaenea }\end{array}$ & 01 \\
\hline 8 & $\begin{array}{l}\text { Heen Ela, Waga, Colombo District, } \\
\text { Western Province }\end{array}$ & $\begin{array}{l}6^{0} 54^{\prime} 21 \mathrm{~N} \& 80^{\circ} 07^{\prime} 40 \mathrm{E} ; \\
18.3 \mathrm{~m}\end{array}$ & $\begin{array}{l}\text { Water canal } \\
\text { River bank }\end{array}$ & August 2003 & $\begin{array}{l}\text { Cylindera (Ifasina) } \\
\text { labioaenea }\end{array}$ & 01 \\
\hline 9 & $\begin{array}{l}\text { Siriniwasa Stream, Waga, Colombo } \\
\text { District, Western Province }\end{array}$ & $\begin{array}{l}6^{0} 50^{\prime} 11 \mathrm{~N} \& 80^{\circ} 07^{\prime} 02 \mathrm{E} ; \\
12.9 \mathrm{~m}\end{array}$ & $\begin{array}{l}\text { Stream } \\
\text { Rocks }\end{array}$ & May 2013 & $\begin{array}{l}\text { Cylindera (Ifasina) } \\
\text { labioaenea }\end{array}$ & 01 \\
\hline 10 & $\begin{array}{l}\text { Kelani River, Malwana, Gampaha } \\
\text { District, Western Province }\end{array}$ & $\begin{array}{l}6^{0} 56^{\prime} 84 \mathrm{~N} \& 80^{\circ} 00^{\prime} 75 \mathrm{E} ; \\
23.2 \mathrm{~m}\end{array}$ & $\begin{array}{l}\text { Major river } \\
\text { River bank }\end{array}$ & August 2003 & $\begin{array}{l}\text { Cylindera (Ifasina) } \\
\text { labioaenea }\end{array}$ & 03 \\
\hline 11 & $\begin{array}{l}\text { Kelani River, Kirielamulla, Gampaha } \\
\text { District, Western Province }\end{array}$ & $\begin{array}{l}6^{0} 56^{\prime} 86 \mathrm{~N} \& 80^{\circ} 00^{\prime} 66 \mathrm{E} \\
12.8 \mathrm{~m}\end{array}$ & $\begin{array}{l}\text { Major river } \\
\text { Amongst grasses of } \\
\text { river bank. }\end{array}$ & August 2003 & $\begin{array}{l}\text { Cylindera (Ifasina) } \\
\text { labioaenea }\end{array}$ & 02 \\
\hline 12 & $\begin{array}{l}\text { Kelani River, Kaduwela, Colombo } \\
\text { District, Western Province }\end{array}$ & $\begin{array}{l}6^{0} 56^{\prime} 13 N \text { \& } 79^{\circ} 59^{\prime} 07 E ; \\
22.9 m\end{array}$ & $\begin{array}{l}\text { Major river } \\
\text { Moist rocks }\end{array}$ & August 2003 & $\begin{array}{l}\text { Cylindera (Ifasina) } \\
\text { labioaenea }\end{array}$ & 02 \\
\hline 13 & $\begin{array}{l}\text { Water canal, Handapangoda, } \\
\text { Kalutara District, Western Province }\end{array}$ & $\begin{array}{l}6^{0} 47^{\prime} 05 \mathrm{~N} \& 80^{\circ} 08^{\prime} 03 \mathrm{E} \\
23.0 \mathrm{~m}\end{array}$ & $\begin{array}{l}\text { Water canal } \\
\text { Moist rocks }\end{array}$ & July 2003 & $\begin{array}{l}\text { Cylindera (Ifasina) willeyi } \\
\text { Cylindera (Ifasina) } \\
\text { waterhousei }\end{array}$ & $\begin{array}{l}01 \\
02\end{array}$ \\
\hline 14 & $\begin{array}{l}\text { Bopath Falls, Kuruwita, Ratnapura } \\
\text { District, Sabaragamuwa Province }\end{array}$ & $\begin{array}{l}6^{\circ} 48^{\prime} 06 \mathrm{~N} \& 80^{\circ} 22^{\prime} 04 \mathrm{E} \\
16.5 \mathrm{~m}\end{array}$ & $\begin{array}{l}\text { Waterfall } \\
\text { River bank }\end{array}$ & August 2003 & $\begin{array}{l}\text { Cylindera (Ifasina) } \\
\text { waterhousei }\end{array}$ & 05 \\
\hline 15 & $\begin{array}{l}\text { Deduru Oya, Halawatha, Puttalam } \\
\text { District, North-Western Province }\end{array}$ & $\begin{array}{l}7^{\circ} 60^{\prime} 28 \mathrm{~N} \& 79^{\circ} 81^{\prime} 18 \mathrm{E} \\
81.43 \mathrm{~m}\end{array}$ & $\begin{array}{l}\text { River } \\
\text { River banks }\end{array}$ & May 2014 & Calomera angulata & 02 \\
\hline
\end{tabular}

as medium sized tiger beetles. When considering the body length, labioaenea was significantly smaller than willeyi and waterhousei, and angulata was significantly smaller than cardoni. However, significant differences were only evident between small and medium sized beetles according to body weight (Table 3 ).

\section{Habitat Parameters}

The climatic and soil parameters for the riverine locations of tiger beetles is given in Table 4 . When considering the comparison between habitat parameters of the locations of labioaenea and locations of other species, significant differences were evident. Air temperature and solar radiation was high $(p<0.05)$ in the locations of labioaenea than of the other species, while relative humidity was significantly low (Table 5).

\section{DISCUSSION}

Cylindera (Ifasina) labioaenea was the most common tiger beetle species and occurred as a single species population in all its locations. Calomera cardoni co-occurred with Calomera angulata at Ma Oya, while willeyi co-occurred with waterhousei at the stream in Handapangoda.

When examining the body size of species, labioaenea was the smallest species with a significantly lower body 
Table 3. Average values ( \pm standard error of mean) and the range (within brackets) of body weight and body length of tiger beetle species of riverine locations.

\begin{tabular}{|l|c|l|l|}
\hline Species & $\begin{array}{l}\text { Number of } \\
\text { Specimens }\end{array}$ & $\begin{array}{l}\text { Average Body } \\
\text { Weight }(\mathbf{m g})\end{array}$ & $\begin{array}{l}\text { Body Length } \\
(\mathbf{m m})\end{array}$ \\
\hline $\begin{array}{l}\text { Cylindera (Ifasina) } \\
\text { labioaenea }\end{array}$ & 21 & $\begin{array}{l}18.20^{\mathrm{a}} \pm 0.96 \\
(9.20-28.80)\end{array}$ & $\begin{array}{l}7.85^{\mathrm{a}} \pm 0.12 \\
(7.05-8.90)\end{array}$ \\
\hline $\begin{array}{l}\text { Cylindera (Ifasina) } \\
\text { willeyi }\end{array}$ & 08 & $\begin{array}{l}27.45^{\mathrm{a}} \pm 1.32 \\
(23.10-32.30)\end{array}$ & $\begin{array}{l}9.19^{\mathrm{b}} \pm 0.11 \\
(8.68-9.60)\end{array}$ \\
\hline $\begin{array}{l}\text { Cylindera (Ifasina) } \\
\text { waterhousei }\end{array}$ & 07 & $\begin{array}{l}24.76^{\mathrm{a}} \pm 2.10 \\
(16.30-34.10)\end{array}$ & $\begin{array}{l}8.80^{\mathrm{b}} \pm 0.27 \\
(7.55-9.08)\end{array}$ \\
\hline Calomera cardoni & 03 & $\begin{array}{l}78.37^{\mathrm{b}} \pm 12.99 \\
(55.40-100.30)\end{array}$ & $\begin{array}{l}13.18^{\mathrm{c}} \pm 0.74 \\
(11.70-14.00)\end{array}$ \\
\hline Calomera angulata & 03 & $\begin{array}{l}66.73^{\mathrm{b}} \pm 11.96 \\
(44.40-85.30)\end{array}$ & $\begin{array}{l}10.72^{\mathrm{d}} \pm 0.10 \\
(10.55-10.89)\end{array}$ \\
\hline
\end{tabular}

Means sharing a common letter (s) within the same column are not significantly different according to Tukey's multiple comparison test.

weight and body length. In turn, the habitats of the species had a significantly high air temperature and solar radiation, and a low relative humidity reflecting comparatively warm, dry environments. In terrestrial arthropods the body size of ants has been shown to decrease with temperature whereas bees, butterflies and moths show a variety of body size-climate patterns (Entling et al. 2010). In tiger beetles large body size has been associated with coastal and reservoir habitats with high wind speed, low soil moisture and high soil $\mathrm{pH}$, while species with small body have been associated with riverine habitats with low wind speed, high soil moisture and low soil pH (Dangalle et al. 2013). The interspecific mechanism, starvation resistance predicts an increase in body size towards cold environments (Greenberg 1979; Entling et al. 2010), while accelerated maturation leads to smaller adult size at high temperatures (Entling et al. 2010). Increased temperature is known to increase development and growth rates, shortening development time resulting in reduced adult size (Kingsolver \& Huey 2008). Thus, in light of these conditions smaller tiger beetles can be expected in warmer riverine ecosystems while comparatively larger species may occur in more moist, cold riverine habitats.

We further observed that $C$. labioaenea occurs as a single species population in all its locations while the other species co-exist. Hoback et al. (2001) has shown that in sympatric tiger beetles, larger species may act as intraguild predators on smaller species. In the present study, C. willeyi and C. waterhousei that co-existed at Handapangoda were statistically similar in size (body lengths $9.19 \pm 0.11$ and $8.80 \pm 0.27$ respectively), while the sympatric Calomera cardoni and $C$. angulata were both in the medium size range (body lengths $13.18 \pm 0.74$ and
Table 4. Climatic and soil parameters of the riverine locations at which tiger beetles were recorded.

\begin{tabular}{|l|l|l|}
\hline Habitat Parameter & Average value \pm Std. Error & Range \\
\hline $\begin{array}{l}\text { Air temperature }\left({ }^{\circ} \mathrm{C}\right) \\
(\mathrm{n}=30)\end{array}$ & $35.13 \pm 0.53$ & $31.00-41.00$ \\
\hline $\begin{array}{l}\text { Solar radiation }\left(\mathrm{w} / \mathrm{m}^{2}\right) \\
(\mathrm{n}=30)\end{array}$ & $385.93 \pm 46.38$ & $92.00-949.00$ \\
\hline $\begin{array}{l}\text { Relative humidity (\%) } \\
(\mathrm{n}=30)\end{array}$ & $59.87 \pm 1.18$ & $47.00-69.00$ \\
\hline $\begin{array}{l}\text { Wind speed (MPH) } \\
(n=30)\end{array}$ & $0.67 \pm 0.27$ & $0.00-5.00$ \\
\hline $\begin{array}{l}\text { Soil temperature }\left({ }^{\circ} \mathrm{C}\right) \\
(\mathrm{n}=24)\end{array}$ & $31.54 \pm 0.62$ & $26.00-39.00$ \\
\hline $\begin{array}{l}\text { Soil pH } \\
(n=24)\end{array}$ & $6.01 \pm 0.22$ & $4.20-7.20$ \\
\hline $\begin{array}{l}\text { Soil salinity (ppt) } \\
(n=24)\end{array}$ & 0.00 & - \\
\hline $\begin{array}{l}\text { Soil colour } \\
(n=24)\end{array}$ & Yellow to Dark brown & - \\
\hline $\begin{array}{l}\text { Soil moisture (\%) } \\
(n=22)\end{array}$ & $16.31 \pm 3.68$ & $1.64-52.92$ \\
\hline
\end{tabular}

$10.72 \pm 0.10$ respectively). According to Hoback et al. (2001), smaller species compensate for predation risk by defensive behaviours including a shift in habitat use and a change in foraging activity in the presence of the larger species. However, the present study indicates that the smallest species, C. labioaenea, may have completely avoided the habitats of the larger species as a defensive strategy after experiencing predatory encounters. More investigations and more sampling in riverine locations are required to provide more evidence to this fact.

When considering the habitat preferences tiger beetles, were found foraging at air temperatures of $35.13 \pm 0.53{ }^{\circ} \mathrm{C}$. Tiger beetle activity is highly dependent on air temperature and many species display maximum activity at an optimal temperature range that is decided by thermoregulatory mechanisms, desiccation and prey availability (Dreisig 1980; Schultz \& Hadley 1987). Our data suggests that the optimal temperature range of the riverine tiger beetles lies between $31.00-41.00{ }^{\circ} \mathrm{C}$.

Tiger beetles are also sensitive to soil moisture, soil salinity and soil temperature of locations due to preferences in oviposition and larval development (Romey \& Knisley 2002; Cornelisse \& Hafernik 2009). When considering soil moisture, high percentages are found in riverine ecosystems $(16.31 \pm 3.68)$ when comparing with the reservoir ecosystems $(4.25 \pm 0.67)$

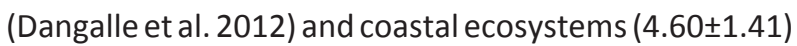
(Dangalle et al. 2013b) of tiger beetles. As C. labioaenea, C. willeyi, C. waterhousei and Calomera cardoni were restricted to riverine ecosystems and not observed in other habitat types, it is possible that soil moisture is a key factor contributing to the habitat preference 
Table 5. Comparison of the habitat parameters of the riverine locations of Cylindera labioaenea and other tiger beetle species (" $n$ " denotes the number of times from which habitat parameters were recorded from locations. Values are given as average \pm standard error and range is given within brackets)

\begin{tabular}{|c|c|c|c|c|c|c|c|c|c|}
\hline Species & $\begin{array}{c}\text { Air } \\
\text { temp. }\left({ }^{\circ} \mathrm{C}\right)\end{array}$ & $\begin{array}{c}\text { Incident } \\
\text { Solar } \\
\text { Radiation } \\
\left(\mathrm{w} / \mathrm{m}^{2}\right)\end{array}$ & $\begin{array}{c}\text { Relative } \\
\text { Humidity } \\
(\%)\end{array}$ & $\begin{array}{l}\text { Wind } \\
\text { Speed } \\
\text { (MPH) }\end{array}$ & $\begin{array}{l}\text { Soil temp. } \\
\qquad\left({ }^{\circ} \mathrm{C}\right)\end{array}$ & Soil pH & Soil colour & $\begin{array}{l}\text { Soil salinity } \\
\text { (ppt) }\end{array}$ & $\begin{array}{c}\text { Soil } \\
\text { moisture } \\
(\%)\end{array}$ \\
\hline $\begin{array}{l}\text { Cylindera labioaenea } \\
\qquad(n=20)\end{array}$ & $\begin{array}{c}35.80^{\mathrm{a}} \pm \\
0.59 \\
(32.00- \\
41.00)\end{array}$ & $\begin{array}{l}469.90^{\mathrm{a}} \\
\pm 57.42 \\
(92.00- \\
949.00)\end{array}$ & $\begin{array}{c}56.80^{\mathrm{a}} \pm \\
1.28 \\
(47.00- \\
67.00)\end{array}$ & $\begin{array}{c}0.80^{\mathrm{a}} \pm \\
0.38 \\
(0.00- \\
5.00)\end{array}$ & $\begin{array}{c}32.57^{\mathrm{a}} \pm \\
0.69 \\
(30.00- \\
39.00) \\
(\mathrm{n}=14)\end{array}$ & $\begin{array}{c}5.60^{\mathrm{a}} \pm \\
0.30 \\
(4.20- \\
7.00) \\
(\mathrm{n}=14)\end{array}$ & $\begin{array}{l}\text { Yellow } \\
\text { to Dark } \\
\text { reddish- } \\
\text { brown }\end{array}$ & $0.00^{\mathrm{a}}$ & $\begin{array}{c}23.02^{\mathrm{a}} \pm \\
5.89 \\
(3.12- \\
52.92) \\
(\mathrm{n}=12)\end{array}$ \\
\hline $\begin{array}{l}\text { All other species } \\
\qquad(n=10)\end{array}$ & $\begin{array}{c}33.80^{\mathrm{b}} \pm \\
0.98 \\
(31.00- \\
41.00)\end{array}$ & $\begin{array}{c}218.00^{\mathrm{b}} \\
\pm 46.59 \\
(104.00- \\
481.00)\end{array}$ & $\begin{array}{c}66.00^{\mathrm{b}} \pm \\
0.59(64.00 \\
-69.00)\end{array}$ & $\begin{array}{c}0.40^{\mathrm{a}} \pm \\
0.31(0.00 \\
-3.00)\end{array}$ & $\begin{array}{c}30.10^{\mathrm{a}} \pm \\
0.99(26.00 \\
-35.00)\end{array}$ & $\begin{array}{c}6.58^{\mathrm{a}} \pm \\
0.21 \\
(5.00- \\
7.20)\end{array}$ & $\begin{array}{l}\text { Yellowish } \\
\text { brown } \\
\text { to Dark } \\
\text { yellowish- } \\
\text { brown }\end{array}$ & $0.00^{\mathrm{a}}$ & $\begin{array}{c}8.25^{\mathrm{a}} \pm \\
2.27 \\
(1.64- \\
18.82)\end{array}$ \\
\hline
\end{tabular}

Means sharing a common letter (s) within the same column are not significantly different according to Tukey's multiple comparison test.

of species. Soil temperature in riverine ecosystems is low $\left(31.54 \pm 0.62{ }^{\circ} \mathrm{C}\right)$ when comparing with reservoir ecosystems $\left(33.64 \pm 2.1{ }^{\circ} \mathrm{C}\right.$ ) (Dangalle et al. 2012) and coastal ecosystems $\left(34.71 \pm 0.95{ }^{\circ} \mathrm{C}\right.$ ) (Dangalle et al. $2013 \mathrm{~b}$ ) suggesting that this factor may also contribute to the habitat preferences of riverine tiger beetles. When considering soil colour, tiger beetles are known to occur in soils which match their structural colouration. Blending of structural colouration with the colour of the surrounding soil enables tiger beetles to evade attack from natural enemies such as birds, bats and robberflies (Seago et al. 2009). As tiger beetles collected from riverine habitats were mainly dark brown and bronze with light yellow elytral maculations and spots, their preference to soils of yellow to dark brown is apparent. Further, we observed that tiger beetles of riverine ecosystems prefer soils with non-saline conditions.

Calomera angulata which is common to reservoir habitats of Sri Lanka (Dangalle et al. 2012) was also observed in riverine ecosystems. However, as they were discovered in only two locations, the preference of the species for riverine habitats needs to be further investigated.

As the riverine ecosystems provide refugia to two endemic tiger beetle species of the country as well as other tiger beetles better decisions regarding the design, planning and implementation of conservation strategies of these ecosystems are required.

\section{REFERENCES}

Acciavatti, R.E. \& D.L. Pearson (1989). The tiger beetle genus Cicindela (Coleoptera: Insecta) from the Indian subcontinent. Annals of Carnegie Museum 58(4): 77-355.

Bhargav, V.K. \& V.P. Uniyal (2008). Communal roosting of tiger beetles (Cicindelidae: Coleoptera) in the Shivalik Hills, Himachal Pradesh, India. Cicindela 40(1-2): 1-12.

Cornelisse, T.M. \& J.E. Hafernik (2009). Effects of soil characteristics and human disturbance on Tiger Beetle oviposition. Ecological Entomology 34: 495-503; http://dx.doi.org/10.1111/j.13652311.2009.01093.x

Dangalle, C., N. Pallewatta \& A. Vogler (2011). The current occurrence, habitat and historical change in the distribution range of an endemic Tiger Beetle species Cicindela (Ifasina) willeyi Horn (Coleoptera: Cicindelidae) of Sri Lanka. Journal of Threatened Taxa 3(2): 1493-1505; http://dx.doi.org/10.11609/JoTT.o2501.1493-505

Dangalle, C., N. Pallewatta \& A. Vogler (2012). Tiger beetles (Coleoptera: Cicindelidae) of ancient reservoir ecosystems of Sri Lanka. Journal of Threatened Taxa 4(4): 2490-2498; http://dx.doi. org/10.11609/JoTT.o2896.2490-8

Dangalle, C.D., N. Pallewatta \& A.P. Vogler (2013a). The association between body-size and habitat-type in tiger beetles (Coleoptera, Cicindelidae) of Sri Lanka. Ceylon Journal of Science (Bio. Sci.) 42(1): 41-53; http://dx.doi.org/10.4038/cjsbs.v42i1.5898

Dangalle, C.D., N. Pallewatta \& A.P. Vogler (2013b). The current status of the tiger beetle species of the coastal habitats of Sri Lanka. Journal of Tropical Forestry and Environment 3(2): 39-52.

Dreisig, H. (1980). Daily activity, thermoregulation and water loss in the tiger beetle Cicindela hybrida. Oecologia 44: 376-389.

Entling, W., M.H. Schmidt-Entling, S. Bacher, R. Brandl \& W. Nentwig (2010). Body size - climate relationships of European spiders. Journal of Biogeography 37: 477-485; http://dx.doi.org/10.1111/ j.1365-2699.2009.02216.x

Fowler, W.W. (1912). Fauna of British India including Ceylon and Burma \{Coleoptera general introduction and Cicindelidae and Paussidae\}. Indian reprint by Today and Tomorrow's Printers and Publishers, New Delhi, 529pp.

Greenberg, R. (1979). Body size, breeding habitat, and winter exploitation systems in Dendroica. The Auk 96: 756-766.

Hoback, W.W., L.G. Higley \& D.W. Stanley (2001). Tigers eating tigers: evidence of intraguild predation operating in an assemblage of tiger beetles. Ecological Entomology 26: 367-375; http://dx.doi. org/10.1046/j.1365-2311.2001.00333.x

Horn, W. (1904). The Cicindelidae of Ceylon. Spolia Zeylanica 2(5): 30-45.

Hudgins, R., C. Norment, M.D. Schlesinger \& P.G. Novak (2011). Habitat selection and dispersal of the Cobblestone Tiger Beetle (Cicindela marginipennis Dejean) along the Genesee River, New York. American Midland Naturalist 165: 304-318.

Kingsolver, J.G. \& R.B. Huey (2008). Size, temperature, and fitness: three rules. Evolutionary Ecology Research 10: 251-268.

Lorenz, W. (1998). Systematic list of extant ground beetles of the 
world (Insecta Coleoptera "Geo-adephaga:" Trachypachidae and Carabidae incl. Paussinae, Cicindelinae, Rhysodinae). Tutzing, Germany, 490pp.

McCairns, R.F., R. Freitag, H.A. Rose \& F.J.D. McDonald (1997). Taxonomic revision of the Australian Cicindelidae (Coleoptera), excluding species of Cicindela. Invertebrate Taxonomy 11: 599-687.

Pearson, D.L. (2011). Six-legged tigers. Spring 19-23.

Pearson, D.L., C.B. Knisley \& C.J. Kazilek (2006). A field guide to the tiger beetles of the United States and Canada: Identification, natural history, and distribution of the Cicindelidae. Oxford University Press, New York, 221pp.

Romey, W.L. \& C.B. Knisley (2002). Microhabitat segregation of two Utah sand dune tiger beetles (Coleoptera: Cicindelidae). The Southwestern Naturalist 47(2): 169-174.

Schultz, T.D. \& N.F. Hadley (1987). Microhabitat segregation and physiological differences in co-occurring tiger beetle species,
Cicindela oregona and Cicindela tranquebarica. Oecologia 73: 363370.

Seago, A.E., P. Brady, J.P. Vigneron \& T.D. Schultz (2009). Gold bugs and beyond: a review of iridescence and structural colour mechanisms in beetles (Coleoptera). Journal of the Royal Society Interface, 6: 165-184.

Shook, G. \& W. Xiao-Qiang (2006). Tiger beetles (Coleoptera: Cicindelidae) of the Red River, Yunnan Province, China. Cicindela 38(1-4): 37-46

Wiesner, J. (1992). Checklist of the tiger beetles of the world (Coleoptera: Cicindelidae). Verlag Erna Bauer, Keltern, Germany, 364pp.

Zerm, M. \& J. Adis (2001). Spatio-temporal distribution of larval and adult tiger beetles (Coleoptera: Cicindelidae) from open habitats in Central Amazonian floodplains (Brazil). Studies of Neotropical Fauna \& Environment 36(3): 185-198.

Appendix A. Raw habitat data of sampling locations of tiger beetles.

\begin{tabular}{|c|c|c|c|c|c|c|c|c|c|}
\hline Location & $\begin{array}{l}\text { Air Temp. } \\
\quad\left({ }^{\circ} \mathrm{C}\right)\end{array}$ & $\begin{array}{c}\text { Incident } \\
\text { Solar } \\
\text { Radiation } \\
\left(\mathrm{w} / \mathrm{m}^{2}\right)\end{array}$ & $\begin{array}{c}\text { Relative } \\
\text { Humidity } \\
\text { (\%) }\end{array}$ & $\begin{array}{l}\text { Wind } \\
\text { Speed } \\
\text { (MPH) }\end{array}$ & $\begin{array}{l}\text { Soil Temp. } \\
\quad\left({ }^{\circ} \mathrm{C}\right)\end{array}$ & Soil pH & Soil Colour & $\begin{array}{c}\text { Soil } \\
\text { Salinity } \\
\text { (ppt) }\end{array}$ & $\begin{array}{c}\text { Soil } \\
\text { Moisture } \\
(\%)\end{array}$ \\
\hline Ma Oya, Alawwa & 32,32 & 246,250 & 64,68 & 3,1 & 28,30 & $7.0,7.2$ & $\begin{array}{l}\text { Yellowish- } \\
\text { brown }\end{array}$ & $0.0,0.0$ & $1.64,1.70$ \\
\hline We Oya, Yatiyantota & $38,39.2$ & 221,223 & 52,54 & 0,0 & 35,39 & $7.0,7.0$ & $\begin{array}{l}\text { Strong } \\
\text { brown }\end{array}$ & $0.0,0.0$ & $8.50,8.52$ \\
\hline $\begin{array}{l}\text { Maha Oya Falls, Dehi } \\
\text { Owita }\end{array}$ & 33,35 & 231,233 & 58,60 & 0,0 & \multicolumn{5}{|c|}{ Found on moist rocks with no soil. } \\
\hline $\begin{array}{l}\text { Maha Oya, Dehi } \\
\text { Owita }\end{array}$ & 31,33 & 131,133 & 65,65 & 0,0 & $27.5,28.5$ & $6.7,6.9$ & $\begin{array}{l}\text { Yellowish- } \\
\text { brown }\end{array}$ & $0.0,0.0$ & $2.88,2.90$ \\
\hline $\begin{array}{l}\text { Seethavaka River, } \\
\text { Thalduwa }\end{array}$ & 35,37 & 945,949 & 57,59 & 0,0 & 32,33 & $6.3,6.5$ & $\begin{array}{c}\text { Dark } \\
\text { yellowish- } \\
\text { brown }\end{array}$ & $0.0,0.0$ & $\begin{array}{l}12.06 \\
12.10\end{array}$ \\
\hline $\begin{array}{l}\text { Asvathu Oya, } \\
\text { Awissawella }\end{array}$ & 32,34 & 712,716 & 65,67 & 3,5 & 30,32 & $6.3,6.5$ & $\begin{array}{l}\text { Yellowish- } \\
\text { brown }\end{array}$ & $0.0,0.0$ & $3.12,3.28$ \\
\hline $\begin{array}{l}\text { Water Canal, } \\
\text { Puvakpitiya }\end{array}$ & 32,34 & 261,263 & 64,66 & 0,0 & 30,32 & $6.1,6.3$ & Yellow & $0.0,0.0$ & - \\
\hline Heen Ela, Waga & $36,36.8$ & 492,498 & 47,51 & 0,0 & 30,36 & $4.4,4.8$ & $\begin{array}{l}\text { Strong } \\
\text { brown }\end{array}$ & $0.0,0.0$ & $\begin{array}{l}12.00 \\
15.90 \\
\end{array}$ \\
\hline $\begin{array}{l}\text { Siriniwasa Stream, } \\
\text { Waga }\end{array}$ & 33,33 & 92,94 & 56,62 & 0,0 & \multicolumn{5}{|c|}{ Found on rocks with no soil. } \\
\hline Kelani River, Malwana & 38,38 & 576,580 & 51,55 & 0,0 & 30,32 & $4.2,4.6$ & $\begin{array}{c}\text { Dark } \\
\text { brown }\end{array}$ & $0.0,0.0$ & $\begin{array}{l}51.50 \\
52.92 \\
\end{array}$ \\
\hline $\begin{array}{l}\text { Kelani River, } \\
\text { Kirielamulla }\end{array}$ & 36,40 & 572,584 & 53,53 & 4,4 & 32,33 & $4.2,4.2$ & $\begin{array}{c}\text { Dark } \\
\text { reddish- } \\
\text { brown }\end{array}$ & $0.0,0.0$ & $47,49.38$ \\
\hline $\begin{array}{l}\text { Kelani River, } \\
\text { Kaduwela }\end{array}$ & 35,41 & 571,585 & 50,56 & 0,0 & \multicolumn{5}{|c|}{ Found on rocks with no soil. } \\
\hline $\begin{array}{l}\text { Water Canal, } \\
\text { Handapangoda }\end{array}$ & 32,32 & 125,127 & 65,65 & 0,0 & 26,28 & $5.0,7.0$ & $\begin{array}{c}\text { Dark } \\
\text { yellowish- } \\
\text { brown }\end{array}$ & $0.0,0.0$ & $\begin{array}{l}17.10 \\
18.82\end{array}$ \\
\hline $\begin{array}{l}\text { Bopath Falls, } \\
\text { Kuruwita }\end{array}$ & 33,35 & 104,106 & 65,65 & 0,0 & 31,32 & $6.0,6.2$ & $\begin{array}{c}\text { Dark } \\
\text { yellowish- } \\
\text { brown }\end{array}$ & $0.0,0.0$ & $3.75,3.91$ \\
\hline $\begin{array}{l}\text { Deduru Oya, } \\
\text { Halawatha }\end{array}$ & 37,41 & 477,481 & 69,69 & 0,0 & 35,35 & $6.8,7.0$ & $\begin{array}{l}\text { Brownish- } \\
\text { yellow }\end{array}$ & $0.0,0.0$ & $\begin{array}{l}14.65 \\
15.16\end{array}$ \\
\hline
\end{tabular}


Appendix B. Raw morphometric data for tiger beetles.

\begin{tabular}{|l|c|l|l|}
\hline Species & $\begin{array}{l}\text { Number of } \\
\text { specimens } \\
\text { measured }\end{array}$ & Body weight (mg) & Body length (mm) \\
\hline Cylindera (Ifasina) labioaenea & 21 & $\begin{array}{l}14.80,22.80,14.20,16.30,17.10,14.60,17.10, \\
17.70,16.90,21.80,28.80,17.20,20.70,18.80, \\
17.20,20.70,15.50,27.30,17.60,9.20,15.9\end{array}$ & $\begin{array}{l}7.05,8.00,7.73,7.28,8.30,7.30,7.70,8.00,7.83, \\
7.10,7.30,7.30,8.50,8.70,8.28,8.00,8.00,7.28,\end{array}$ \\
\hline Cylindera (Ifasina) willeyi & 08 & $\begin{array}{l}32.30,25.80,23.40,27.80,31.20,23.10,31.30, \\
24.70\end{array}$ & $9.45,8.88,8.68,9.20,9.35,9.40,9.00,9.60$ \\
\hline Cylindera (Ifasina) waterhousei & 07 & $28.30,34.10,16.30,24.80,21.80,22.60,25.40$ & $7.55,9.90,8.53,8.75,9.08,8.78,9.00$ \\
\hline Calomera cardoni & 03 & $79.4,55.4,100.3$ & $13.85,11.70,14.00$ \\
\hline Calomera angulata & 03 & $44.4,70.50,85.30$ & $10.55,10.71,10.89$ \\
\hline
\end{tabular}

